\title{
CANNABINOID-MEDIATED REGULATION OF THE HYPOTHALAMO- PITUITARY-ADRENAL AXIS IN RATS: AGE DEPENDENT ROLE OF VASOPRESSIN
}

\author{
Istvan Barna, Katalin Csabai, Gabor B. Makara, Dora Zelena \\ Institute of Experimental Medicine, Hungarian Academy of Sciences, 1083 Budapest, Szigony 43. Hungary \\ e-mail: zelena@koki.hu
}

\begin{abstract}
Objective. Adaptation to stress is a fundamental component of life and the hypothalamo-pituitary-adrenocortical axis (HPA) plays a crucial role in it. The place of cannabinoid influence seems to be in the brain, especially where corticotropin releasing hormone and vasopressin (AVP) secreting neurons are located. The role of AVP is considered to be more important in young than in adult rats. Here we addressed the question if cannabinoid-mediated regulation of the HPA involves AVP and if there is any difference between young and adult rats in this process.

Methods. 10-day-old and adult AVP deficient Brattleboro rats were compared with their heterozygous littermates $1 \mathrm{~h}$ after WIN 55,212-2 (6mg/kg i.p.) injection.

Results. In control animals the injection led to elevated adrenocorticotropin (ACTH) and corticosterone hormone levels at both ages without remarkable age difference in ACTH levels while all corticosterone levels of adults was approximately 10-times higher. The ACTH secretion of young AVP deficient rats failed to react to WIN 55,212-2 injection while their corticosterone levels were even higher than their littermates. In contrast in adult the role of AVP was diminished.

Conclusions. We can conclude that the peripheral administration of cannabinoids leads to HPA axis stimulation, which process involves AVP at least in the young rats. The discrepancy between $\mathrm{ACTH}$ and corticosterone levels in young rats suggests an alternative adrenal gland regulatory pathway, which might be present in all studied animals. However, it comes to the front just in AVP deficient pups.
\end{abstract}

Key words: WIN 55,212-2 - Vasopressin - Neonatal period - Adulthood - ACTH - Corticosterone

The cloning of the cannabinoid receptors (MATSUDA et al. 1990; MunRo et al. 1993) and the identification of endogenous cannabinoid ligands (Devane et al. 1992; Mechoulam et al. 1995) prompted a large interest in the functions of the endogenous cannabinoid system. The cannabinoid CB1 receptor is expressed in various regions of the brain and was shown to play important roles in locomotion, pain perception, memory, feeding, anxiety, etc. (Herkenham et al. 1991; PorTER et al. 2001). In addition to their neural and behavioral effects, exogenous cannabinoids affect the production of various hormones, including the gonadal steroids,

Corresponding author: Dr. Dóra Zelena, Hungarian Academy of Sciences, Institute of Experimental Medicine, 1083 Budapest, Szigony 43, Hungary. Phone: +36-1-210-9400/290, Fax: +36-1-210-9951, e-mail: zelena@koki.hu

Abbreviations: $\mathrm{ACTH}=$ adrenocorticotropin; $\mathrm{AVP}=$ arginine vasopressin; $\mathrm{CB} 1=$ cannabinoid receptor 1 type; $\mathrm{CRH}=$ corticotropin releasing hormone; di/+= heterozygous Brattleboro (AVP-deficient) animals; di/di = homozygous Brattleboro (AVP-deficient) rats; $\mathrm{DMSO}=$ dimethylsulfoxide; EDTA = ethylene diamine tetra-acetic acid; HPA = hypothalamo-pituitary-adrenal axis; i.p. = intraperitoneal; PVN = paraventricular hypothalamic nucleus; RIA = radioimmunoassay; THC = delta (9)-tetrahydrocannabinol; V = vehicle; WIN = WIN 55,212-2 
growth hormone, prolactin, thyroid hormones and glucocorticoids (BROwN et al. 2002). There are a series of studies suggesting that endogenous cannabinoid system also play a role in the control of the hypothalamopituitary-adrenal axis (HPA), e.g. BARNA et al. (2004). Early studies showed that peripherally administered delta (9)-tetrahydrocannabinol (THC), as well as the widely used CB1 agonist WIN 55,212-2 (WIN) stimulates adrenocorticotropin (ACTH) secretion (BORCEL et al. 2004; PUDER et al. 1982). Later studies revealed that the cannabinoid receptors are expressed at the level of both the hypothalamus and pituitary, suggesting that the effects of cannabinoids on the HPA-axis are direct (i.e. mediated by their receptors) and not necessarily related to their sedative or cognitive effects (HERKENHAM et al. 1991). Despite their presence on the pituitary our previous work, as well as the study of Di et al. suggested that the main site of the cannabinoid-dependent HPA axis influence is rather the hypothalamus (BARNA et al. 2004; Di et al. 2003).

In adult rats mainly two hypothalamic peptides, corticotropin releasing hormone $(\mathrm{CRH})$ and arginine vasopressin (AVP) control the ACTH release from the anterior pituitary. Both are secreted into the hypophyseal portal circulation by neurons located in the parvocellular region of the paraventricular hypothalamic nucleus (PVN) and stimulate ACTH secretion (SAPOLSKY et al. 1986). ACTH reaches the adrenal gland through systemic circulation and the consequence is an increased secretion of glucocorticoids. The relative contributions of CRH and AVP to ACTH release seem to be stressor-specific, however there is a consensus that in adulthood the release is controlled mainly by CRH, while AVP is just support its effect (DE KLOET 2003; ScOTT et al. 1998).

On the other hand, during perinatal period AVP seems to be the predominant secretagogue of the ACTH, while the glucocorticoid regulation of hypothalamic CRH gene expression is not matured (AvISHAIELINER et al. 1995; GRINO et al. 1989; LEVINE 2002). In rats the HPA-axis is already functional in late gestation with high plasma corticosterone levels. However, plasma levels decrease dramatically during the first two postnatal days and remain low until postnatal day 14 (WALKER et al. 1986). During this period the response of the HPA-axis to stressful stimuli (e.g. exposure to ether vapors or cold, endotoxin injection, maternal deprivation or electroshocks) is markedly reduced compared with the large responses seen in adult rats ( $\mathrm{S}_{\mathrm{A}-}$ POLSKY et al. 1986). This stress hyporesponsive period was demonstrated in both rat pups and children and has major implications for the maturation of the HPAaxis (GUNNAR et al. 2002; SAPOLSKY et al. 1986).

The aim of the present experiments was to investigate the role of AVP in the cannabinoid dependent HPAaxis regulation with special attention on age differences. To study the role of AVP the AVP-deficient Brattleboro rat is a good experimental model. This strain was discovered in mid 60's and shows an inherited single nucleotide deletion at the neurophysin II region of the AVP precursor molecule, which results in an abnormal AVP prohormone. This is not processed normally, consequently rats lack functional AVP and show diabetes insipidus (EvANs et al. 2000).

\section{Materials and Methods}

Animals. The experiment was performed in 10-dayold and adult (8-10 weeks old) male Wistar (Charles River, Hungary) and Brattleboro rats (our colony with parent stocks from Harlan Laboratories; Indianapolis, IN, USA). The 0 day was determined when the offspring was found with the mother on the usual observation at around $9.00 \mathrm{~h}$. Litter size was 3-12 and was not controlled. Only the male offspring was used for this experiment. Homozygous (di/di) AVP-deficient animals were compared to their heterozygous (di/+) littermates (BoHus et al. 1998; ZelenA et al. 2003). Brattleboro breeding pairs consisted of a di/+ female and a di/di male. The rats were kept in a controlled environment (temperature: $23 \pm 1{ }^{\circ} \mathrm{C}$; relative humidity: 50 $70 \%$ ) with $12 / 12 \mathrm{~h}$ day/night schedule (lights on at 7.00 h) and were fed on a commercial rat chow (Charles River Laboratories, Hungary) and had free access to tap water.

Experiments were carried out between 9-12h a.m., in accordance with the European Communities Council Directive of 24 November 1986 (86/609/EEC) and were reviewed and approved by the Animal Welfare Committee of the Institute of Experimental Medicine.

Experimental design. Experiment 1. In the first phase of the study, to get an adequate dose for the later experiment, we performed a pilot experiment on 10-day-old Wistar rats using 0-0.3-1-3 mg/kg WIN (Tocris; $1 \mu \mathrm{l} / \mathrm{g}$ ) dissolved in dimethylsulfoxide (DMSO, vehicle, V). The doses of the compound, the route of administration as well as the time were chosen on the basis of the literature and was not toxic, e.g. BORCEL et al. (2004) and MARTin-CALderon (1998). In fact, there were no data available about the effect of WIN 
on the ACTH levels in 10-day-old rats, but it seemed that $60 \mathrm{~min}$ is needed for the development of nociceptive effect (BorCEL et al. 2004), since also MARTINCALDERon et al. (1998) used the same timing for studying the effect of another CB1 receptor agonist, HU210. The pups got an intraperitoneal (i.p.) injection than they were returned back to their homecage/mother and decapitated $1 \mathrm{~h}$ later. The trunk blood was collected on $20 \mu \mathrm{l} 20 \% \mathrm{~K}_{2}$-EDTA (ethylene diamine tetra-acetic acid) containing ice-cold Eppendorf tubes. After centrifugation $(3000 \mathrm{rpm} / \mathrm{min}$ for $20 \mathrm{~min}$ at -4 ${ }^{\circ} \mathrm{C}$ ) plasma was frozen at $-20{ }^{\circ} \mathrm{C}$ until hormone measurement ( $\mathrm{n}=7-11)$.

Experiment 2 was done on 10-day-old Brattleboro pups. In each litter half of the pups was injected i.p. with WIN $(6 \mathrm{mg} / \mathrm{kg}, 1 \mu \mathrm{l} / \mathrm{g}$ body weight; dissolved in V) while the other half was injected with the same amount of V. After injection all pups was returned to their dam and decapitated $1 \mathrm{~h}$ later. Trunk blood was collected as described above and whole pituitary was put in $100 \mu \mathrm{l} 0.1 \mathrm{~N} \mathrm{HCl}$ and stored there at $-20{ }^{\circ} \mathrm{C}$ until homogenization for AVP measurement ( $\mathrm{n}=14-18)$.

Experiment 3 was done on adult Brattleboro rats. The genotype of the rats was inferred upon their water consumption in their 4 week old age, which means they were separated for 3-4 days, than were kept 3-4 rats/ cage until experiment. The animals were separated (one animal per cage) for 1 week and weighed on the day before the experiment. On the day of experiment rats were injected i.p. with $6 \mathrm{mg} / \mathrm{kg}$ WIN or V and $1 \mathrm{~h}$ later they were decapitated. Trunk blood was collected on $\mathrm{K}_{2}$-EDTA into ice-cold tubes $(\mathrm{n}=15-18)$.

Experiment 4 was done in adult Wistar rats to study the strain dependent effect of WIN, as the WIN was able to induce only a small ACTH and corticosterone rise in adult Brattleboro rat. The animals were kept one/ cage 1 week prior the experiment and were weighed the day before the experiment. $\mathrm{V}$ or $6 \mathrm{mg} / \mathrm{kg}$ WIN were injected i.p. and the animals were killed by decapitation $1 \mathrm{~h}$ later. Trunk blood was collected on ice-cold, $\mathrm{K}_{2}$-EDTA containing tubes ( $\left.\mathrm{n}=9-10\right)$.
Hormone assays. Plasma ACTH was measured by radioimmunoassay (RIA) in $50 \mu \mathrm{l}$ unextracted plasma as described earlier (BARNA et al. 2004; ZelenA et al. 1999). The ACTH antibody was raised in rabbit in the Institute of Experimental Medicine, Hungarian Academy of Sciences (Budapest, Hungary) and was directed against the middle part of the h-ACTH-1-39 molecule. The intra-assay coefficient of variation was $7.23 \%$. All the samples from a particular experiment were assessed in the same RIA.

Plasma corticosterone was measured in $10 \mu \mathrm{lnex}-$ tracted plasma by a RIA using a specific antibody developed in our Institute as described earlier (ZELENA et al. 2003). The corticosterone antibody was raised in rabbits against B-carboximethyloxime bovine serum albumin. The intraassay coefficient of variation was $7.5 \%$. All the samples from a particular experiment were measured in one RIA.

AVP content was also measured by RIA. Pituitaries were collected on $100 \mu \mathrm{l} 0.1 \mathrm{~N} \mathrm{HCl}$ and were frozen to $-20^{\circ} \mathrm{C}$. After thawing, pituitaries were boiled for $5 \mathrm{~min}$, after which they were ultrasonically homogenized and refrozen. On the next day, samples were thawed and centrifuged for $20 \mathrm{~min}$ at $3000 \mathrm{rpm}$. The supernatant was stored at $-20{ }^{\circ} \mathrm{C}$ till hormone measurements. The rabbit anti-AVP antiserum was obtained from dr. M. Vecsernyés (Szent-Györgyi Medical University, Szeged, Hungary). The intra- and inter-assay coefficients of variation were 10.7 and $17.7 \%$, respectively.

Statistical evaluation was performed by the STATISTICA 6.0 Software (Statistica Inc., Tulsa, USA). Data (expressed as mean \pm SEM) were analyzed by factorial ANOVA. Only statistically significant effects and interactions were mentioned in the results. The Newman-Keuls test was used for post-hoc comparisons. $\mathrm{P}<0.05$ was considered statistically significant.

\section{Results}

The effect of WIN 55,212-2 in pups. The preliminary experiment on Wistar pups (Table 1) revealed that the smaller doses of WIN $(0.3$ or $1 \mathrm{mg} / \mathrm{kg})$ did not in-

Table 1

Effect of WIN 55,212-2 in 10-day-old Wistar pups

\begin{tabular}{lcccc}
\hline & $\mathrm{V}$ & \multicolumn{3}{c}{ WIN 55,212-2 } \\
\cline { 2 - 5 } & & $0.3 \mathrm{mg} / \mathrm{kg}$ & $1 \mathrm{mg} / \mathrm{kg}$ & $3 \mathrm{mg} / \mathrm{kg}$ \\
\hline ACTH $(\mathrm{fmol} / \mathrm{ml})$ & $35.5 \pm 3.2$ & $30.4 \pm 1.6$ & $35.2 \pm 5.0$ & $71.9 \pm 21.1^{*}$ \\
\hline
\end{tabular}

$* \mathrm{p}<0.05$ vs. vehicle treated control 


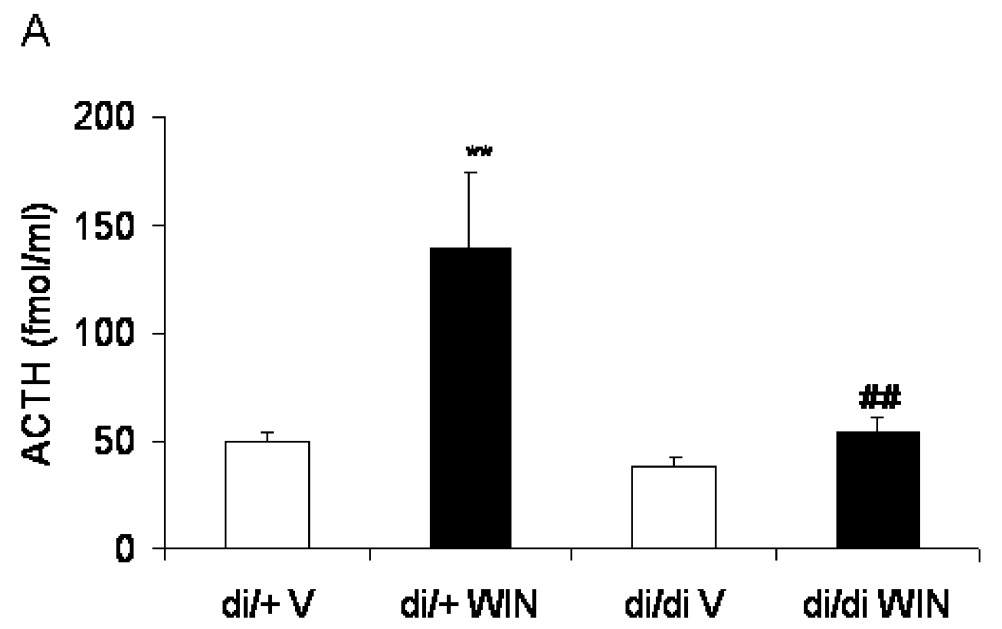

B

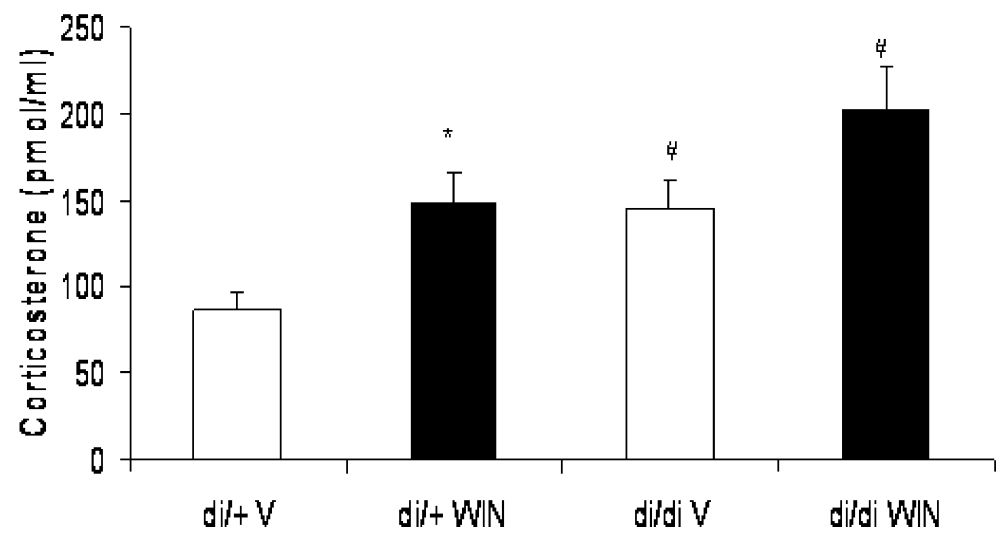

Fig. 1 (A) ACTH (fmol/ml) and (B) corticosterone (pmol/ml) plasma levels in 10-day-old Brattleboro pups $1 \mathrm{~h}$ after i.p. injection of $6 \mathrm{mg} / \mathrm{kg}$ WIN $55,212-2$. ${ }^{*} \mathrm{p}<0.05 ;{ }^{* *} \mathrm{p}<0.01$ vs. vehicle treated control; \#p<0.05; \#\#p<0.01 vs. di/+ pups of the same treatment

duce significant ACTH elevation $1 \mathrm{~h}$ after its i.p. administration, while the highest dose used $(3 \mathrm{mg} / \mathrm{kg})$ significantly elevated it (approx. 2-fold; $\mathrm{p}=0.04$ ) $[F(3,33)=2.7, p=0.06]$. As we wanted to be sure that the ACTH elevating effect will be present we have chosen $6 \mathrm{mg} / \mathrm{kg}$ for later studies.

The genotype of the Brattleboro pups were determined at the end of the experiments upon their pituitary AVP content (di/+: $25.6 \pm 1.7 \mathrm{ng} /$ pituitary; di/di: $0.44 \pm 0.07 \mathrm{ng} /$ pituitary). The AVP levels of di/di rats were under the detection limit and were significantly lower than those for $\mathrm{di} /+$ pups $[\mathrm{F}(1,65)=174.1, \mathrm{p}<0.01]$.

The i.p. administration of WIN resulted in a significant ACTH elevation at $60 \mathrm{~min}$ (approx. 2.8fold; Fig.1A) [treatment: $\mathrm{F}(1,65)=8.5, \mathrm{p}<0.01$ ]. The AVP-deficient pups had lower ACTH levels in all stud- ied groups with no remarkable effect of WIN revealed by significant treatment*genotype interaction [genotype: $\mathrm{F}(1,65)=7.1, \mathrm{p}<0.01$; treatment*genotype: $\mathrm{F}(1,65)=4.1, \mathrm{p}=0.047]$.

Surprisingly, the accompanied corticosterone levels showed different pattern (Fig.1B). Administration of WIN resulted in a significant elevation of the plasma corticosterone levels in both genotypes (di/+: 1.7-fold; di/di: 1.4-fold) without treatment*genotype interaction [treatment: $\mathrm{F}(2,97)=19.9, \mathrm{p}<0.01]$. However the vehicle treated AVP-deficient rats showed elevated corticosterone levels, which was similar to WIN-injected $\mathrm{di} /+$ groups (about 1.5 -fold increase in both case) [genotype: $\mathrm{F}(1,97)=14.6, \mathrm{p}<0.01]$.

Effect of WIN 55,212-2 in adults. The genotype of the adult Brattleboro rats was inferred in 4-week-old 

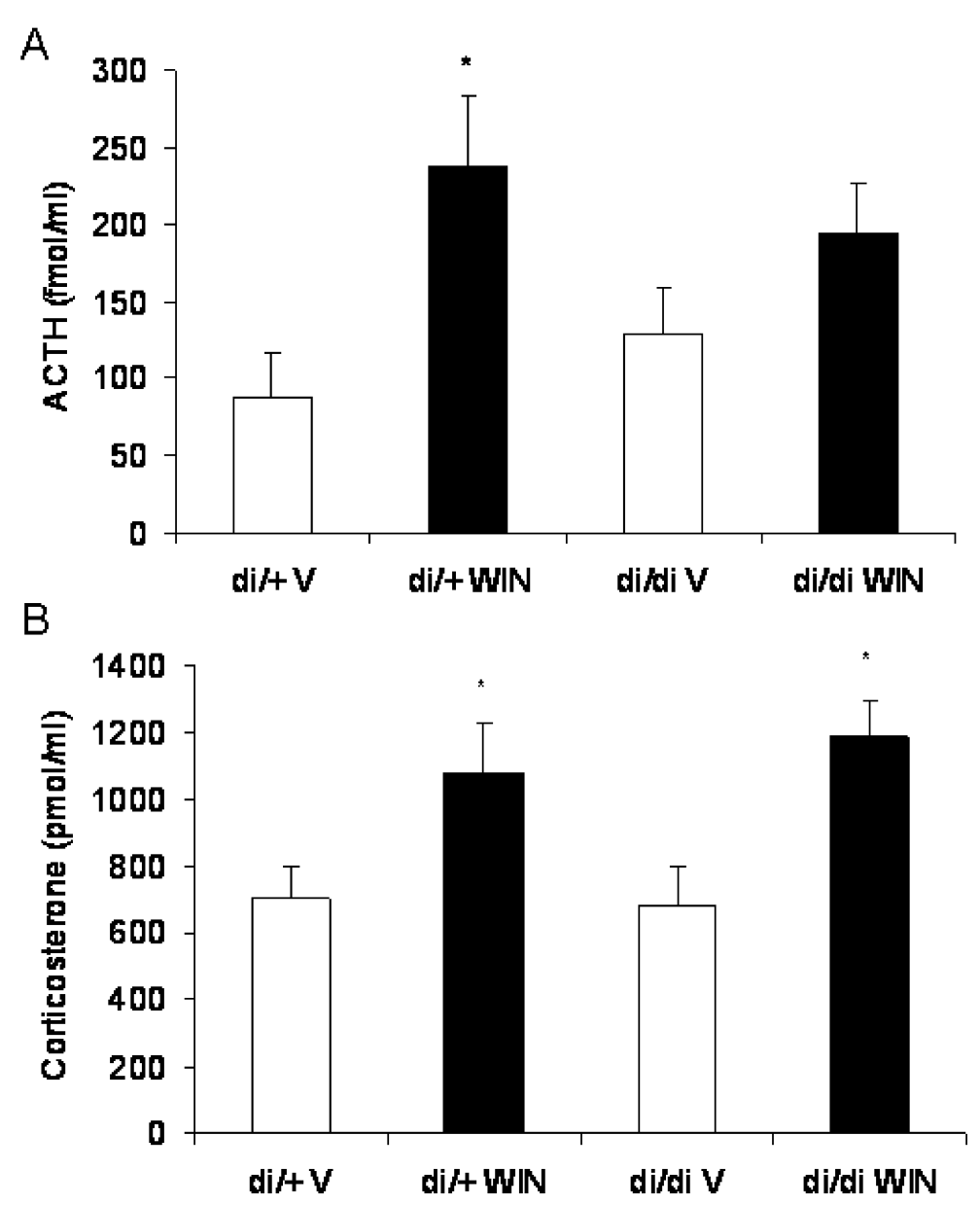

Fig. 2 (A) ACTH (fmol/ml) and (B) corticosterone (pmol/ml) plasma levels in adult Brattleboro rats $1 \mathrm{~h}$ after i.p. injection of 6mg/kg WIN 55,212-2. *p<0.05 vs. vehicle treated control

animals upon the water consumption, which was approximately 3-times more in di/di rats than in their heterozygous littermattes $(\mathrm{di} /+: 20.7 \pm 0.7 \mathrm{ml} / \mathrm{rat}$; di/di: $58.9 \pm 2.2 \mathrm{ml} / \mathrm{rat})[\mathrm{F}(1,65)=274.2, \mathrm{p}<0.01]$.

In Brattleboro strain the i.p. WIN injection was able to induce significant ACTH rise in both genotype without any effect of the AVP-deficiency (Fig. 2A) [treatment: $F(1,60)=9.7, p<0.01$; no further significance]. However in control, di/+ animals the ACTH elevation was 2.7 -fold, while in di/di only 1.5 -fold.

Similarly to the ACTH levels the WIN-induced corticosterone rises (approx. 1.5-fold) was also independent from the presence or absence of AVP (Fig. 2B) [treatment: $\mathrm{F}(1,63)=14.5, \mathrm{p}<0.01]$.

In adult Wistar animals the i.p. injection of WIN elevated both the ACTH (14-fold) and corticosterone (3.6-fold) levels $60 \mathrm{~min}$ after its administration. (Fig. 3) $[\mathrm{ACTH}: \mathrm{F}(1,17)=76.1, \mathrm{p}<0.01$; corticosterone: $\mathrm{F}(1,18)=39.9, \mathrm{p}<0.01]$.

\section{Discussion}

The injection of the cannabinoid CB1 receptor agonist WIN was able to stimulate the HPA axis both in 10-day-old offspring and adult as could be seen on plasma ACTH and corticosterone levels. The mediator of this phenomenon seems to be the AVP during the perinatal period however its importance diminished in later life.

There is substantial evidence indicating that cannabinoid receptor agonists induce a CB1-receptor mediated activation of the HPA axis in both adult (MANZA- 


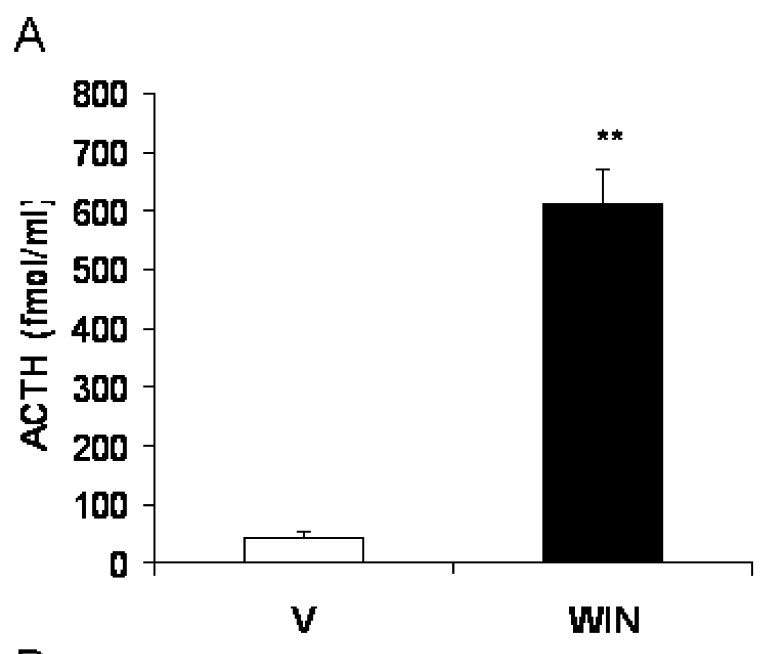

$\mathrm{B}$

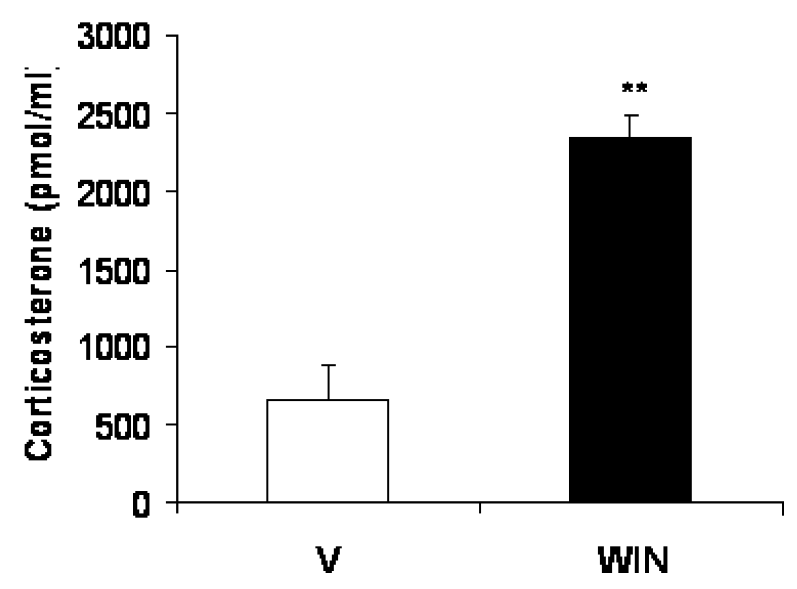

Fig. 3 (A) ACTH (fmol/ml) and (B) corticosterone (pmol/ml) plasma levels in adult Wistar rats $1 \mathrm{~h}$ after i.p. injection of $6 \mathrm{mg} / \mathrm{kg}$ WIN 55,212-2.*p<0.05; **p<0.01 vs. vehicle treated control

NARES et al. 1999) and juvenile rats (ROMERo et al. 2002). However a previous work of BORCEL et al. (2004) indicated that at postnatal day 20 the cannabinoid system of the rat is immature and did not respond to $3 \mathrm{mg} / \mathrm{kg}$ WIN (BorCEL et al. 2004). This later finding is in contrast to our work as we were able to find a significant ACTH as well as corticosterone elevating effect of 3-6 $\mathrm{mg} / \mathrm{kg}$ WIN in the 10-day-old rat. An explanation could be that BorCEL et al. (2004) measured the hormone levels at the end of an open field test, so the additional stress may confound the interpretation. Moreover they measured only corticosterone, which is know to react with smaller rises during perinatal period and we also demonstrated that the WIN-induced ACTH elevation was higher (pretty near 3-fold) than the corticosterone rise (approx. 1.5-fold). On the other hand, it was concluded with another CB1 receptor agonist (HU-210) that there were no functional $\mathrm{CB} 1$ receptors in the offspring up to 40 days of age, which could react with HPA axis changes to an exogenous cannabinoid (MARTIN-CALDERON et al. 1998). We could speculate that WIN might have $\mathrm{CB} 1$ receptor-independent function (HowletT 2002). CB2 has also been recently described in central nervous system and could account for some previously reported cannabinoid-mediated effects (ONAIVI et al. 2006). Increasing pharmacological evidence also suggest that other putative cannabinoid receptors coexist within CNS, e.g. the novel described GPR55 (that, however, do not bind WIN) (SAWZDARGO et al. 1999). Moreover, anandamide, the first described endocannabinoid, has been reported to activate HPA axis increasing both ACTH and corticosterone by an unknown cannabinoid receptor (WENGER et al. 2003). The known $\mathrm{CB} 1$ and the unidentified $\mathrm{CBx}$ receptors apparently share common activities in the brain, as e.g. regulating the $\mathrm{CRH}$-erg cells in the nuclues paraventricularis hypothalami (KofALVI et al. 2003, WENGER et al. 1997).

The central mediation of cannabinoid effects on HPA-axis is supported by several studies. In hypothalamic slice preparations WIN mimicked the HPA axis suppressing effects of glucocorticoids (Di et al. 2003), additionally in an in vitro system it was completely ineffective on the pituitary ACTH release as well as on the glucocorticoid feedback at the same level (BARNA et al. 2004). Our data add further detail as we were able to demonstrate that the AVP-erg neurons plays a crucial role in the cannabinoid mediated HPA axis regulation, which effect seems to be age dependent. There are several possible sites in the brain where AVP may interact with the cannabinoid receptors. As the PVN thought to be the main regulator of the HPA and has a large amount of AVP, it is the more thinkable nucleus (Di et al. 2003). Although the magnocellular part of the PVN contains larger amount AVP but the fewer AVP in the parvocellular part supposed to have a more prominent role in the HPA axis regulation (ANTONI 1993; WotJAK et al. 2002). Supporting this theory it was already established, that systemic application of anandamide lead to c-fos elevation in the parvocellular PVN (WENGER et al. 1997). However we cannot close out the possibile involvement of other brain areas as well (e.g. septum or amygdala, (GERST- 
BERGER et al. 1989; Tsou et al. 1998). Moreover one can hypothesize that endocannabinoid signalling in different brain structures plays different roles in the control of HPA axis.

It is known that the HPA axis function is changing with age. For example in aged rats the recovery after stress is delayed (SAPOLSKY et al. 1984). However in our hands both in young and adult Brattleboro rats the i.p. administration of $6 \mathrm{mg} / \mathrm{kg}$ WIN resulted in similar HPA axis elevation (ACTH: 2.8-2.7-fold increase; Corticosterone: 1.7-1.5-fold increase). The contribution of different peptides in the HPA axis regulation can be also changed. It was demonstrated that the regulation of hypothalamic CRH gene expression was not mature during the perinatal period (GRINO et al. 1989), whereas the regulation of hypothalamic AVP gene expression matured very early (TRIBOLLET et al. 1991). In the offspring the insulin-induced hypoglycemia increased the ACTH and corticosterone secretion via AVP mediation (MURET et al. 1992). Our results support the theory that during the perinatal period the AVP is the predominant secretagogue of the ACTH secretion in the rat. In adult rat the relative importance of $\mathrm{CRH}$ and AVP in the regulation of the HPA activity is not so clear. Although several work suggested that the HPA axis regulatory role of AVP became more important during chronic stimuli, we failed to confirm this statement in our previous works (MAKARA et al. 2004, ZelenA et al. 2006). Moreover, we found that the role of AVP is more prominent, although not exclusive, in acute stress situations. With WIN we were able to demonstrate only a slight tendency for diminished ACTH secretion in AVP deficient adult animals. Therefore we conclude that the role of AVP in the cannabinoid-mediated HPA axis stimulation diminishes with age. However we have to take into consideration the development of compensatory mechanisms as well (eg. elevated CRH mRNA levels in PVN of adult Brattleboro rats (MLYNARIK et al. 2007)).

The different peptides may have species dependent effect as well. According to the general assumption the main ACTH secretagogue in adult rat is the CRH while in sheep the AVP (ANTONI 1993). As there are several studies confirming differences in the HPA axis of rat or mice strains, for instance that by REDEI et al. (1994), we assumed that there might be a difference between the cannabinoid sensitivity of generally used Wistar rats and the Brattleboro rats used in our study. Our result confirmed our hypothesis as we found that in Wistar rats the same amount of WIN induced approximately 5-fold higher ACTH elevation than in Brattleboro rat. The parallel corticosterone elevation was 2.5-fold higher in Wistars, probably as a consequence of the different time-course of the two hormone. The background of this phenomenon could be some differences in the number, affinity or distribution of the $\mathrm{CB} 1$ (or $\mathrm{CBx}$ ) cannabinoid receptors in the two strain.

The discrepant ACTH and corticosterone levels in pups were also surprising and suggested a local, ACTH-independent regulation of the corticosterone secretion. It might be that these signals are present also among normal conditions, but are covered by the main regulator, ACTH. In the absence of the main signal, however, a minor cannabinoid-dependent regulation may come into highlight. It was already demonstrated, although in rabbit, that from whole isolated adrenal glands the in vitro adrenalin release was dose dependently decreased by WIN (NIEDERHOFFER et al. 2001). The strong correlation between stressinduced catecholamine and HPA axis regulation led us to hypothesize, that local cannabinoid-mediated regulation may be involved also in the regulation of corticosterone secretion, either directly or through regulation of the medullary adrenalin release. Actually there have been reports of CB1 expression in the adrenal gland, at least during embryonic stage (BuCKLEY et al. 1998). We cannot exclude a presence a yet unidentified cannabinoid receptor subtype, too (KoFALVI et al. 2003).

In the present study we were able to demonstrate an age and strain dependent cannabinoid-mediated HPA axis activation, which - at least in pups- strongly dependent on the presence of AVP. In the absence of ACTH a local cannabinoid-dependent regulation may come to the front to stimulate the glucocorticoid secretion from the adrenal gland.

\section{Acknowledgements}

Supported by T 043161, NN71629 OTKA and 059/ 2006 ETT grants. 


\section{References}

ANTONI FA: Vasopressinergic control of pituitary adrenocorticotropin secretion comes of age. Front Neuroendocrinol 14, 76-122, 1993

Avishai-Eliner S, Yi SJ, Newth CJ, Baram TZ: Effects of maternal and sibling deprivation on basal and stress induced hypothalamic-pituitary-adrenal components in the infant rat. Neurosci Lett 192, 49-52, 1995

Barna I, Zelena D, Arszovszki AC, Ledent C: The role of endogenous cannabinoids in the hypothalamo-pituitaryadrenal axis regulation: in vivo and in vitro studies in CB1 receptor knockout mice. Life Sci 75, 2959-2970, 2004

Bohus B, DE WIED D: The vasopressin deficient Brattleboro rats: a natural knockout model used in the search for CNS effects of vasopressin. Prog Brain Res 119, 555-573, 1998

Borcel E, Perez-Alvarez L, de Ceballos ML, Ramirez BG, Marco EM, Fernandez B, Rubio M, Guaza C, Viveros MP: Functional responses to the cannabinoid agonist WIN 55,212-2 in neonatal rats of both genders: influence of weaning. Pharmacol Biochem Behav 78, 593-602, 2004

BRown TT, Dobs AS: Endocrine effects of marijuana. J Clin Pharmacol 42, 90S-96S, 2002

Buckley NE, Hansson S, Harta G, Mezey E: Expression of the CB1 and CB2 receptor messenger RNAs during embryonic development in the rat. Neuroscience 82, 1131-1149, 1998

DE KLOET ER: Hormones, brain and stress. Endocr Regul 37, 51-68, 2003

Devane WA, Hanus L, Breuer A, Oertwee RG, Stevenson la, Mendelbaum A, Etinger A, Mechoulam R: Isolation and structure of a brain constituent that binds to the cannabinoid receptor. Science 258, 1946-1949, 1992

Di S, Malcher-Lopes R, Halmos KC, Tasker JG: Nongenomic glucocorticoid inhibition via endocannabinoid release in the hypothalamus: a fast feedback mechanism. J Neurosci 23, 4850-4857, 2003

Evans DA, De Bree FM, Nijenhuis M, Van Der Kleij AA, Zalm R, Korteweg N, Van Leuveren FW, Burbach JP: Processing of frameshifted vasopressin precursors. J Neuroendocrinol 12, 685-693, 2000

Gerstberger R, FAhrenholz F: Autoradiographic localization of V1 vasopressin binding sites in rat brain and kidney. Eur J Pharmacol 167, 105-116, 1989

Grino M, BuRGUNDER JM, ESKAY RL, EIDEN LE: Onset of glucocorticoid responsiveness of anterior pituitary corticotrophs during development is scheduled by corticotropin-releasing factor. Endocrinology 124, 2686-2692, 1989

Gunnar MR, Donzella B: Social regulation of the cortisol levels in early human development. Psychoneuroendocrinology 27, 199-220, 2002

Herkenham M, Lynn AB, Johnson MR, Melvin LS, de Costa BR, Rice KC: Characterization and localization of cannabinoid receptors in rat brain: a quantitative in vitro autoradiographic study. J Neurosci 11, 563-583, 1991

Howlett AC: The cannabinoid receptors. Prostaglandins Other Lipid Mediat 68-69, 619-631, 2002

Kofalvi A, Vizi ES, Ledent C, Sperlagh B: Cannabinoids inhibit the release of [3H]glutamate from rodent hippocampal synaptosomes via a novel CB1 receptor-independent action. Eur J Neurosci 18, 1973-1978, 2003

LEVINE S: Regulation of the hypothalamic-pituitary-adrenal axis in the neonatal rat: the role of maternal behavior. Neurotox Res 4, 557-564, 2002

Makara GB, Mergl Z, Zelena D: The role of vasopressin in hypothalamo-pituitary-adrenal axis activation during stress: an assessment of the evidence. Ann N Y Acad Sci 1018, 151-161, 2004

Manzanares J, Corchero J, Fuentes JA: Opioid and cannabinoid receptor-mediated regulation of the increase in adrenocorticotropin hormone and corticosterone plasma concentrations induced by central administration of delta(9)tetrahydrocannabinol in rats. Brain Res 839, 173-179, 1999

Martin-Calderon JL, Munoz RM, Villanua MA, del Arco I, Moreno JL, de Fonseca FR, Mavarro M: Characterization of the acute endocrine actions of (-)-11-hydroxy-delta8-tetrahydrocannabinol-dimethylheptyl (HU-210), a potent synthetic cannabinoid in rats. Eur J Pharmacol 344, 77-86, 1998

Matsuda LA, Lolait SJ, Brownstein MJ, Young AC, Bonner TI: Structure of a cannabinoid receptor and functional expression of the cloned cDNA. Nature 346, 561-564, 1990

Mechoulam R, Ben-Shabat S, Hanus L, Ligumsky M, Kaminsky Ne, Shatz AR, Gopher A, Almog S, Martin BR, COMPTON DR: Identification of an endogenous 2-monoglyceride, present in canine gut, that binds to cannabinoid receptors. Biochem Pharmacol 50, 83-90, 1995

Mlynarik M, Zelena D, Bagdy G, Makara GB, Jezova D: Signs of attenuated depression-like behavior in vasopressin deficient Brattleboro rats. Horm Behav 51, 395-405, 2007 
Munro S, Thomas KL, Abu-ShaAr M: Molecular characterization of a peripheral receptor for cannabinoids. Nature $\mathbf{3 6 5}$, 61-65, 1993

Muret L, Priou A, Oliver C, Grino M: Stimulation of adrenocorticotropin secretion by insulin-induced hypoglycemia in the developing rat involves arginine vasopressin but not corticotropin-releasing factor. Endocrinology 130, 2725-2732, 1992

Niederhoffer N, Hansen HH, Fernandez-Ruiz JJ, Szabo B: Effects of cannabinoids on adrenaline release from adrenal medullary cells. Br J Pharmacol 134, 1319-1327, 2001

OnAIVi ES, Ishiguro H, GoNG JP, et al.: Discovery of the presence and functional expression of cannabinoid CB2 receptors in brain. Ann N Y Acad Sci 1074, 514-536, 2006

Porter AC, FELDER CC: (2001): The endocannabinoid nervous system: unique opportunities for therapeutic intervention. Pharmacol Ther 90, 45-60, 2001

Puder M, Weidenfeld J, Chowers I, Nir I, Conforti N, Siegel RA: Corticotrophin and corticosterone secretion following delta 1-Tetrahydrocannabinol, in intact and in hypothalamic deafferentated male rats. Exp Brain Res 46, 8588, 1982

Redei E, PARE WP, Aird F, KLuCZynski J: Strain differences in hypothalamic-pituitary-adrenal activity and stress ulcer. Am J Physiol 266, R353-360, 1994

Romero EM, Fernandez B, Sagredo O, Gomez N, Uriguen L, Guaya C, De Miguel R, Ramos JA, Viveros MP: Antinociceptive, behavioural and neuroendocrine effects of CP 55,940 in young rats. Brain Res Dev Brain Res 136, 8592, 2002

SAPOLSKY RM, KREY LC, McEwEn BS: The neuroendocrinology of stress and aging: the glucocorticoid cascade hypothesis. Endocrine Rev 7, 284-301, 1986

SAPOlSky RM, Krey LC, McEwEn BS, Rainbow TC: Do vasopressin-related peptides induce hippocampal corticosterone receptors? Implications for aging. J Neurosci 4, 1479-1485, 1984

Sawzdargo M, Nguyen T, Lee DK, Lynch KR, Cheng R, Heng HH, George SR, O’Dont BF: Identification and cloning of three novel human G protein-coupled receptor genes GPR52, PsiGPR53 and GPR55: GPR55 is extensively expressed in human brain. Brain Res Mol Brain Res 64, 193-198, 1999

ScotT LV, Dinan TG: Vasopressin and the regulation of hypothalamic-pituitary-adrenal axis function: implications for the pathophysiology of depression. Life Sci 62, 1985-1998, 1998

Tribollet E, Goumaz M, Raggenbass M, Dubois-Dauphin M, Dreifuss JJ: Early appearance and transient expression of vasopressin receptors in the brain of rat fetus and infant. An autoradiographical and electrophysiological study. Brain Res Dev Brain Res 58, 13-24, 1991

Tsou K, Brown S, Sanudo-Pena MC, Mackie K, Walker JM: Immunohistochemical distribution of cannabinoid CB1 receptors in the rat central nervous system. Neuroscience 83, 393-411, 1998

Walker CD, Sapolsky RM, Meaney MJ, Vale WW, Rivier CL: Increased pituitary sensitivity to glucocorticoid feedback during the stress nonresponsive period in the neonatal rat. Endocrinology 119, 1816-1821, 1986

Wenger T, Jamali KA, Juaneda C, Leonardelli J, Tramu G: Arachidonyl ethanolamide (anandamide) activates the parvocellular part of hypothalamic paraventricular nucleus. Biochem Biophys Res Commun 237, 724-728, 1997

Wenger T, LeDENT C, TrAmu G: The endogenous cannabinoid, anandamide, activates the hypothalamo-pituitary-adrenal axis in CB1 cannabinoid receptor knockout mice. Neuroendocrinology 78, 294-300, 2003

Wotjak CT, Ludwig M, Ebner K, Russel JA, Singewald N, Landgraf R: Vasopressin from hypothalamic magnocellular neurons has opposite actions at the adenohypophysis and in the supraoptic nucleus on ACTH secretion. Eur J Neurosci 16, 477-485, 2002

Zelena D, Makara GB, Jezova D: Simultaneous blockade of two glutamate receptor subtypes (NMDA and AMPA) results in stressor-specific inhibition of prolactin and corticotropin release. Neuroendocrinology 69, 316-323, 1999

Zelena D, Mergl Z, MaKara GB: Maternal genotype influences stress reactivity of vasopressin-deficient brattleboro rats. J Neuroendocrinol 15, 1105-1110, 2003

Zelena D, Mergl Z, MaKara GB: The role of vasopressin in diabetes mellitus-induced hypothalamo-pituitary-adrenal axis activation: studies in Brattleboro rats. Brain Res Bull 69, 48-56, 2006 